\title{
Aboriginal Knowledges in Specialized Courts: Emerging Practices in Gladue Courts
}

\author{
Paula Maurutto and Kelly Hannah-Moffat
}

\begin{abstract}
Reforms to Canadian sentencing law in 1996 and the Supreme Court of Canada decision R. v. Gladue [1999] opened the door to a new normative set of legal practices that endeavour to integrate racial knowledge about offenders' collective and individual experiences of race relations and oppression into traditional legal criminal practices. One outcome of the reforms and court cases was the formation of dedicated Gladue courts for Aboriginal peoples. This paper explores the formation of Gladue courts, the legal techniques used to produce contextualized racial knowledges, how this information is admitted as evidence before the court, and how this knowledge is used to reframe legal subjects and the risk they pose.
\end{abstract}

Keywords: Gladue court, sentencing, risk, Indigenous, race relations

\section{Résumé}

Des réformes apportées en 1996 aux lois concernant la détermination de la peine, ainsi que la décision R. c. Gladue de 1999 de la Cour suprême du Canada, ont ouvert la voie à un nouvel ensemble de pratiques normatives visant à intégrer aux pratiques pénales traditionnelles les connaissances sur les expériences collectives et individuelles du contrevenant en matière de relations et d'oppression raciales. L'un des résultats de ces réformes et affaires a été la création de tribunaux Gladue spéciaux pour les personnes autochtones. Cet article examine la création des tribunaux Gladue, les techniques juridiques employées pour obtenir des connaissances raciales contextualisées, la façon par laquelle cette information est prise en compte par la Cour, et la façon par laquelle ces connaissances sont appliquées pour resituer les sujets juridiques et les risques qu'ils posent.

Mots clés : cour, Gladue, prononcé de la peine, risque, Autochtone, relations raciales

\section{Introduction}

Canadian criminal courts are challenging the boundaries of mainstream legal practices by developing techniques and normative practices that locate individual criminal behaviours among Aboriginal peoples within histories of colonialism, race relations, and discrimination. Traditionally, Western legal practices tend to Canadian Journal of Law and Society / Revue Canadienne Droit et Société, 2016, Volume 31, no. 3, pp. 451-471. doi:10.1017/cls.2016.35 
privilege individualized accounts of criminal behaviour while discounting the colonialism and racism experienced by racialized minorities. Consequently, they disqualify or subjugate Aboriginal and racial knowledge (Aylward 1999; Crenshaw 2005; Dei, et al. 2002; Delgado and Stefancic 2000; Matsuda 1996; Monture-Angus 1999; Williams 2009). The exclusion of Indigenous knowledges and disregard of the role of colonialism and racial discrimination in criminal proceedings is being credited for perpetuating the overrepresentation of racial minorities, in particular Aboriginal peoples, within the criminal justice system. Reforms to Canadian sentencing law in 1996 and the Supreme Court of Canada decision R. v. Gladue [1999] did little to alter incarceration rates, but they did open the door for a new normative set of practices intended to reconstitute the Aboriginal legal subject (Daubney 2002; Rudin and Roach 2002; Vancise and Healy 2002).

One outcome of the R. v. Gladue decision was the formation of dedicated Gladue courts for Aboriginal peoples in Toronto (Campbell Research Associates 2008; Knazan 2003, 2005, 2009). Gladue courts are regular criminal courts that apply Canadian law in cases involving Aboriginal offenders, but they are distinctive in their approach to sentencing. ${ }^{1}$ These courts adjudicate bail, conduct trials, and sentence offenders, but they do so by integrating specialized Aboriginal knowledge to produce alternative understandings of an Aboriginal accused so that bail orders and sentences conform to the intent of the R. v. Gladue decision. To ensure adherence to Gladue principles, the court is presented with information that locates an Aboriginal defendant's behaviour within collective histories and experiences of oppression. In addition, alternatives to custody and information about the factors that perpetuate patterns of over-incarceration are also brought before the court. To accomplish these goals, Gladue courts rely on a team of court workers hired and/or trained by Aboriginal Legal Services of Toronto. These Aboriginal court workers play a critical role in educating legal professionals; they write specialized reports that contextualize the accused's behaviour and connect the accused to community resources (Knazan 2005, 2009).

Our paper seeks to understand how R. v. Gladue, R. v. Ipeelee and, more specifically, Gladue courts, give rise to new legal practices that seek to integrate information about Aboriginal cultural factors and histories into traditional legal procedures. In this study, we used observational data collected from two Gladue courts in Toronto to determine how legal practitioners use their own situated understandings of Aboriginal experiences, while also frequently drawing on new forms of Indigenous expertise, to change the courts' characterization of an accused's temperament, pattern of offending, and likelihood of recidivism, and to justify an alternative sanction. We draw on court observations taken over a total of twenty months spanning three years, from 2009 to 2011. Over this time, we observed a total of 1,032 cases; the number observed per day ranged from

1 Gladue courts differ from Aboriginal persons' courts in other parts of the country (e.g., the Saskatchewan Cree Court and Calgary's Tsuu T'ina Nation Peacemaking court). They derive their legal status from R. v. Gladue [1999] and specifically apply Canadian criminal law in cases of Aboriginal defendants. 
eight to twenty-six. Our observations and coding focused on the types of evidence and statements presented before the courts. Detailed notes were taken on who was presenting evidence and the types of statements they advanced. ${ }^{2}$ Court observations were supplemented with analyses of court documents and data collected from eleven interviews with judges, lawyers, court workers, and community partners. Additionally, we assessed the content of a sample of six detailed Gladue court reports and Gladue court manuals to understand the format and overall information included in these reports. These data complemented our court observations, and helped us further understand how the reports were used in court cases.

Our interest in Gladue courts is to recognize how knowledge about race and Aboriginal histories enters the courtroom, how this information is used to advance arguments, and how the evidence before the courts is evaluated and deployed to defend the accused. Our analysis was not designed to test whether Gladue courts result in a statistically significant net reduction in incarceration rates. Moreover, while we acknowledge that there is a growing scholarship promoting Indigenous methodologies (Kovach 2010; Hart 2007; Smith 2012), our approach is rooted in Western methods of analysis that are informed by critical race, Foucaultian, and feminist approaches. This analysis is intended to examine how the integration of contextualized Aboriginal knowledges in Gladue courts allow legal professionals to raise new legal arguments that have the potential of reconstituting the Aboriginal offender and altering sentencing outcomes for Indigenous peoples. We seek to understand the practices, techniques, and strategies used by court workers and lawyers to insert Gladue principles and knowledge into the legal process. We begin with an overview of sentencing reforms and the R. v. Gladue decision that laid the groundwork for the formation of Gladue courts. The discussion of Gladue courts includes an analysis of how contextualized Aboriginal knowledges are incorporated into routine Gladue court practices (i.e., through questions asked of the accused, in statements made by judges and other legal practitioners, and through Gladue reports). We pay particular attention to how contextualized knowledges are reframing legal subjects and the risk they pose, thereby enabling a new set of normative practices.

While there are multiple knowledges circulating in Gladue courts, we analyzed how what we term "contextualized Aboriginal knowledges" are produced and impact court practices. "Aboriginal knowledges" has many connotations; it can refer to Indigenous or traditional teachings, knowledge produced by or about Aboriginal populations, or narratives and oral histories provided by Aboriginal peoples (Battiste and Henderson 2000; Dei et al. 2005; 2002). In our work, contextualized Aboriginal knowledges describe the narratives and evidence appearing in Gladue courts that locate individual behaviour within collective racial histories and experiences of colonialism and discrimination. This definition and the types of evidence it invites differ from the situated individualized knowledge provided

2 We assessed the evidence presented in Gladue courts by comparing it with our observations of conventional courts and other specialized courts. 
by an offender about his or her own life circumstances. Information about an Aboriginal person is not necessarily located within collective histories of systemic discrimination, although it most often is affected by these histories.

Our analysis is informed, in part, by Foucault's concept of power/knowledge (1980a; 1980b; 1994). Foucault's understanding of power/knowledge drew our attention to how contextualized Aboriginal knowledges become counted as credible and worthy evidence before the court. Foucault's insights point to how shifts in law's methods of evaluating and operationalizing knowledge can, at times, operate to expose elements of legal neutrality (Valverde 2003). Historically, Aboriginal knowledges, particularly in criminal cases, have been entirely excluded or positioned as relatively inferior to legal knowledges (Lawrence and Williams 2006; Murdocca 2006). However, since R. v. Gladue, and subsequently R. v. Ipeelee, this evidence is now perceived as legitimate and can potentially be used by lawyers to raise new arguments that may alter longstanding assumptions and claims about Aboriginal risk, criminal histories and breaches, for example. Aboriginal knowledges introduce different evidence into the legal process that may counter the dominant claims made in criminal cases involving Indigenous people. We seek to understand how Aboriginal knowledges interact with traditional legal knowledge to produce a form of racial knowledge that can contextualize an offence committed by an Aboriginal person within broader colonial histories, and potentially use that history to change how law interprets and acts on legal subjectivities. We contend that although Gladue reports may be used in a variety of courts, Gladue courts allow for a specific contextualization of Aboriginal knowledges and histories that does not typically occur in conventional court proceedings.

We also draw on feminist, Indigenous, and critical race analyses of transformative narratives (Aylward 1999; Crenshaw 2005; Delgado 1989; Ewick and Silbey 1995; Hill Collins 2000; Matsuda 1987; Williams 1991). Critical race and feminist legal theories have been instrumental in drawing attention to the power of narratives, stories, and counter-stories to give voice to traditionally silenced individuals, illuminating their histories and providing new possibilities for rewriting social histories (Delgado 1989). Ewick and Silbey's distinction between narratives that support hegemonic stereotypes by "effacing the connections between the particular and the general" and "subversive narratives" that operate by "emplotting" these connections $(1995,219)$ helped us refine our analysis of contextualized knowledges. According to Ewick and Silbey:

[S] ubversive stories do not aggregate to the general, do not collect particulars as examples of a common phenomenon or rule; rather, subversive stories recount particular experiences as rooted in and part of an encompassing cultural, material, and political world that extends beyond the local. $(1995,219)$

This conceptual distinction is useful in differentiating between individual Gladue factors that are associated with Aboriginal disadvantage (i.e., poverty, lack of education, parental substance abuse) and contextualized knowledges that document how these factors are rooted in colonial histories and discrimination (i.e., lack of education related to inadequate state investment, poverty resulting from 
dispossession of land, substance abuse among residential schools survivors). It is these later types of accounts that have "transformative potential"; they root experiences and cultural factors within histories of exploitation (Bell 1991; Delgado 1989; Hill Collins 2000). We draw on this literature to evaluate how contextualized Aboriginal knowledges give rise to alternative ways of constituting offenders and how they are governed and managed. In general, our findings indicate that information generated by lawyers about accused Aboriginal people may identify cultural factors that have led to discrimination, however, this information is not consistently grounded in histories of colonialism and race relations. By contrast, reports produced by trained Gladue writers result in substantially different kinds of knowledge that draw connections between an accused's actions and specific Aboriginal histories of colonialism.

Our analysis is specific to Gladue courts in Canada, but it also has broader implications and significance. Gladue courts illustrate how the historical context of colonialism and racism can be meaningfully integrated into sentencing practices and how this context can be applied to purposefully alter the sentencing practices that contribute to over-incarceration of minority groups. R. v. Gladue, along with subsequent decisions (R. v. Kakekagamick [2006]; R. v. Borde [2003]; $R$. v. Ipeelee [2012]), extends the relevance of contextual inquiry by making courts responsible for taking "judicial notice" of how an accused's behaviour is situated within histories of racial and systemic discrimination. Canadian jurisprudence has signalled that comparable arguments pertaining to contextualized racial history could apply to other marginalized populations. In R. v. Borde [2003], the Ontario Court of Appeal acknowledged that background and systemic factors could be taken into account when imposing sentences for African Canadians, as they are for Aboriginal persons. Similar arguments were advanced in R. v. Hamilton [2005]. However, despite attempts to extend the use of Gladue principles, there remain considerable concerns when courts attempt to use Gladue cultural factors or social context, devoid of any connections to legacies of colonial practices or histories that implicate the state in racial discrimination (see Lawrence and Williams 2006; Murdocca 2006). Within Gladue courts, the connections between Gladue factors and histories of colonialism are expected to be made explicit, thereby allowing for the possibility of a different outcome.

\section{Creating Spaces for Contextualized Aboriginal Knowledges}

\section{A Review of Sentencing Law and Supreme Court Decisions}

The first major reform and codification of sentencing principles in the history of Canadian criminal law was introduced under Bill C-41 in 1995. The sentencing reforms came into effect on 3 September 2016. These amendments, in particular section 718.2(e) of the Criminal Code, altered the guidelines used by judges and provided specific provisions for the sentencing of Aboriginal offenders. Prior to these reforms, information pertaining to an offender's background or narratives of cultural and race histories were, for the most part, rarely considered as relevant evidence in criminal justice proceedings. Section 718 enabled evidence of contextualized Aboriginal knowledges to enter the courtroom. 
The Supreme Court of Canada case R. v. Gladue (1999) ruled on the application and interpretation of section 718.2(e). This decision acknowledged what countless commissions and reports have documented: discrimination within the legal and criminal justice systems has contributed to a crisis of over-incarceration (Law Reform Commission of Canada 1991; Royal Commission on Aboriginal Peoples 1996). ${ }^{3}$ Moreover, it affirmed that the overrepresentation of Aboriginals is not simply related to social disadvantage but to the more complex legacy of colonialism (Rudin and Roach 2002); a theme reaffirmed by the Truth and Reconciliation Commission of Canada (2015). To address this problem, R. v. Gladue directed judges to alter conventional legal practice, specifically instructing judges to:

[T] ake judicial notice of the broad systemic and background factors affecting Aboriginal people, and of the priority given in Aboriginal cultures to a restorative approach to sentencing. [paragraph 7]

The decision marked a significant shift in the range of information and evidence to be considered by criminal courts when sentencing Aboriginal offenders. Systemic and background factors can include a broad range of items, but typically include the following Gladue factors:

- Substance abuse - personally, in the immediate family, extended family, and community.

- Poverty - as a child, an adult, within an offender's family, or community.

- Overt/covert racism - in the community, by family members, strangers, school, or workplace.

- Family - quality of relationships, divorce, family involvement in crime, residential school attendance of individual or family members, abandonment, etc.

- Abuse - sexual, emotional, physical, and spiritual.

- Unemployment - low income, lack of employment opportunity.

- Lack of educational opportunities.

- Dislocation from an Aboriginal community.

- Group/community experiences of discrimination.

- Foster care or adoption - age, length of time, by non-Aboriginal family $(R . v$. Kakekagamick 2006; Campbell Research Associates 2008).

Uniquely, R. v. Gladue required that knowledge of general and specific cultural hardships experienced by this group, along with alternatives to incarceration, be requested and brought before the courts. In so doing, the decision explicitly opened a venue for culturally specific and background factors to enter the court. Implicitly, it acknowledged that this evidence is imperative to altering the overreliance on incarceration for this group.

R. v. Gladue marked a significant shift in expectations of judges, placing the onus on the judiciary to collect, address, and reflect on Aboriginal knowledge.

Aboriginal peoples represent only 3 percent of the Canadian adult population, but comprise 22 percent of the Canadian prison population. They are overrepresented in all Canadian jurisdictions (Perreault 2009). 
Typically, the responsibility for providing evidence rests with the defence or prosecution; judges are trained to "stay out of the arena" and leave the submission of arguments and facts to lawyers (Canadian Superior Court Judges Association 2006). However, R. v. Gladue extended and reframed responsibility: it makes the courts (Crown, defence, and judiciary) responsible for ensuring that information specific to Aboriginal circumstances is collected and considered. The decision stipulated that:

even where counsel do not adduce this evidence, where for example the offender is unrepresented, it is incumbent upon the sentencing judge to attempt to acquire information regarding the circumstance of the offender as an Aboriginal person. [paragraph 84]

The requirement that judges be aware of these factors in order to address systemic racism was reiterated in $R$. v. Ipeelee. These decisions shift the balance of responsibility; if the defence or Crown provides insufficient evidence, the judge becomes responsible for ensuring that expert Aboriginal knowledge about the accused is brought before the court in order to sentence the offender in a more innovative and "just" manner. This clear responsibilization of the court runs counter to observable neo-liberal trends in law and penality, which typically devolve responsibility for socio-structural impediments onto individuals and marginalized segments of the population (Garland 2001). According to R. v. Ipeelee, the court is required to consider how "context" matters, how it affects offending, and how it potentially perpetuates the conditions for recidivism.

Despite the decision, trial and appellate courts were confused on when and how to apply Gladue (Rudin 2012). R. v. Ipeelee underscored the fact that Gladue principles were not consistently applied, and Gladue factors were often overlooked in more serious cases. In serious or violent cases, judges were often reluctant to consider Gladue factors or were vague about whether they applied. Moreover, Gladue factors devoid of contextualized understanding often resulted in escalated assessment of risk and punishment (Hannah-Moffat and Maurutto 2010). In addition, courts struggled with understanding how or whether to apply Gladue when a direct link between the offence and the circumstances of the offender were not explicit (Rudin 2012).

Subsequent decisions (R. v. Kakekagamick [2006], R. v. Ipeelee [2012)]) reaffirmed the court's responsibility to collect contextualized knowledge relevant to the sentencing of Aboriginal offenders. In R. v. Ipeelee [2012], the Supreme Court provided additional clarification about the information to be collected and how this evidence might affect "the methodology of assessing a fit sentence." It stated:

To be clear, courts must take judicial notice of such matters as the history of colonialism, displacement, and residential schools and how that history continues to translate into lower educational attainment, lower incomes, higher unemployment, higher rates of substance abuse and suicide, and of course higher levels of incarceration for Aboriginal peoples. These matters, on their own, do not necessarily justify a different sentence for Aboriginal offenders. Rather, they provide the necessary context for understanding and evaluating the case-specific information presented by counsel. [paragraph 60] 
Ipeelee also clarified that courts were to consider Gladue factors in all cases, including serious and violent cases and when the link to an offence was not obvious (Rudin 2012). Additional cases have extended this new method of analysis to include bail (R. v. Bain [2004]; R. v. Crawford [2007]) and parole decisions (R. v. Jensen [2005]) for Aboriginal individuals. In R. v. Ipeelee [2012] the Supreme Court affirmed that these considerations extend to serious violent cases and those sentenced to long-term supervision orders (LTSO).

Notwithstanding the promise of significant reforms, section 718.2(e) and subsequent case law have not significantly altered rates of incarceration for Aboriginal offenders. In fact, the imprisonment of Aboriginal people has increased since R. v. Gladue (Perreault 2009). The Supreme Court of Canada itself recognized in $R$. v. Ipeelee [2012] the "worsening" overrepresentation of aboriginal people following the Gladue decision. Moreover, it reaffirmed the "inadequacy" and "failure" of Canadian courts "to take into account the unique circumstances of Aboriginal offenders that bear on the sentencing process" (2012, paragraphs 75 and 84). R. v. Gladue sparked considerable controversy, and some legal scholars have called the decision a "double-edged sword" that appears progressive but actually masks continuing forms of discrimination and colonialist policies (Balfour 2008; Parkes 2012; Roach and Rudin 2000; Williams 2009). According to Parkes (2012), the implementation of $R$. v. Gladue principals has been confronted with a number of barriers including lack of resources and institutional resistances, both issues that are raised by the Truth and Reconciliation Commission (2015). The lack of resources required to prepare Gladue reports and adequately contextualize Gladue factors, along with the dearth of suitable community services, often make it difficult for defence attorneys to propose convincing submissions for non-custodial sentences (Milward and Parkes 2011). Moreover, Parkes (2012) asserts that Gladue principles are at odds with recent parliamentary legislation that seeks to restrict judicial discretion through mandatory minimums and place limits on the use of conditional sentences served in the community. According to Parkes, mandatory minimums shift the balance of power from the judiciary to prosecutors, and in so doing, increase "charge bargaining" whereby the accused are more likely to plead to lesser charges in order to avoid being subject to mandatory minimums. The impact of mandatory minimums on the over-incarceration of Aboriginal peoples has also been raised as a concern by the Truth and Reconciliation Commission (2015). Parkes notes that Aboriginal peoples "are less likely than other accused to benefit from the exercise of prosecutorial discretion" arising from the proliferation of mandatory sentencing $(2012,25)$. Ultimately, many Aboriginal clients are often persuaded to plead guilty rather than proceed with a time-consuming trial or risk a mandatory sentence (Milward and Parkes 2011). Gladue and Ipeelee do little to address the inherent problem of plea bargaining.

Added to these concerns is the conundrum wherein the identification of Gladue factors, devoid of any connection to histories of colonialism and race relations, often results in an escalated perception of risk and, thereby, potentially more punitive sentences with increased conditions. Factors documented, such as early exposure to violence, dropping out of school, unemployment, alcohol abuse, and mental health concerns, among others, are common indicators of risk. Previously, we argued that 
the restructuring of pre-sentence reports along risk principles, and the incorporation of Gladue factors within such pre-sentence reports, can ultimately increase the perceived risk of Aboriginal peoples who have been marked by complex forms of marginalization (Hannah-Moffat and Maurutto 2010). According to Williams, this is especially true for Aboriginal women where, "claims about Aboriginal women with a simple narrative [...] constructs Aboriginal families as incubators of risk, Aboriginal communities as containers of risk and the prison as a potential source of healing intervention in the defendant's life" (Williams 2009, 95). As noted in feminist and critical race literatures, simply identifying common Gladue factors among Aboriginal peoples obscures the extent to which Gladue factors are the result of histories of colonialism, land dispossession, and discriminatory race relations. Hence, the mere documentation of Gladue factors will have minimal effects on reducing the rates of imprisonment for Indigenous peoples.

Section 718.2(e), R. v. Gladue, and R. v. Ipeelee arguably create space for Aboriginal knowledges and new methodologies but lack the necessary mechanisms to enable meaningful interpretation and application. Our interview data revealed that within conventional court structures, understandings of Aboriginal histories or circumstances continue to be framed by the "common knowledge" of the judiciary or defence counsel, many of whom have limited insight into the specificities of racial discrimination. ${ }^{4}$ Few judges or legal practitioners have a sophisticated understanding of how race relations and collective histories can effectively be used to craft alternative narratives or arguments. Even judges who regularly hear cases involving Aboriginal defendants in conventional criminal courts and who may be familiar with the social and economic realities faced by Aboriginal peoples often lack the sophisticated expertise required to identify and situate social disadvantage within a history of colonialism and discrimination. Milward and Parkes (2011) point to how even in Manitoba, where the majority of all accused persons are Aboriginal, the judiciary lack adequate understanding of how to use Gladue principles to sentence differently. Little guidance is available for the judiciary on how to use Aboriginal knowledge - when it is available - to adjudicate differently. According to Justice Knazan, no judge can:

...attempt to acquire information regarding the circumstances of the offender as an Aboriginal person [or] be made aware of alternatives to incarceration that exist without someone who can talk to the offender, make contacts with community members and resource groups and report to the judge (Knazan 2003, 4-5).

One of our interviewees noted, "the Gladue decision opens the door for defence and Crown to be creative in the sentencing submissions," yet argued that outside of Gladue courts, few know how to use the evidence in innovative ways. In essence, conventional courts lack a sensitized understanding of how to translate this new knowledge into evidence that can alter traditional sentencing and bail practices. Lacking are legal mechanisms that, to use Ewick and Silbey’s term (1995), "emplot"

The term "common knowledge" is borrowed from the work of Valverde (2003) who used the term to describe how judges continue to understand Aboriginal issues within a typically White judicial lens. 
the connections between Gladue factors and how they are rooted in state practices of colonialism and exploitation. Without such connections there is little possibility of reconstituting the Aboriginal legal subject. Hence, R. v. Gladue and R. v. Ipeelee have been compared to other seemingly transformative changes in law that superficially appear "liberating," but continue to be inherently filtered through a White judicial lens that perpetuates historical power relations (Monture-Angus 1999).

\section{Gladue Courts}

In light of this disconnect, a group of judges, academics, and community agencies initiated the construction of a dedicated Gladue court (Knazan 2003, 2005, 2009). Their efforts culminated in Toronto's first Gladue court for Aboriginal peoples, which opened in 2001. By 2006, two additional Toronto courts were operating, and in 2008 the first court outside Toronto was introduced in Sarnia, Ontario. Additionally, Gladue caseworkers, who are hired and trained by Aboriginal legal services, have been funded to provide reports to several courts in Ontario regions (Hamilton/Brantford, Waterloo/Wellington, Manitoulin Island, London, and Thunder Bay). Gladue courts are "regular" Canadian criminal courts applying Canadian law; they do not represent a distinct Aboriginal form of justice. They do, however, acknowledge that the traditional principles of sentencing are problematic and that a new set of legal procedures should be used to address the treatment of Aboriginal offenders. These courts rely on expert information from the community to contextualize Aboriginal histories and identify community supports. Experts from the community are key players in the court. Judge Knazan noted:

[Their] range of expertise will allow the court to craft decisions in keeping with the directive of the Supreme Court in Gladue because the information required to develop such responses will be put before the court (Knazan $2003,10)$.

Gladue courts are distinctively designed to ensure that sentences conform to the principles set out in section 718.2(e).

Gladue courts conduct bail and sentencing hearings. Some dedicated judges and specialized duty counsel (defence) and Crown counsel (prosecutors) work exclusively in these courts and receive specialized training. Additionally, the courts rely on a team of experts, including an Aboriginal bail program supervisor who screens defendants without sureties for eligibility for release; an Aboriginal court worker who assists with securing counsel, preparing release plans, and making referrals to services; a Gladue caseworker entrusted with preparing Gladue reports at sentencing when custody is being considered; and a Gladue aftercare worker who is responsible for post-sentence follow-up. All are trained by, and the latter three are employed by, Aboriginal Legal Services of Toronto (ALST), a non-profit organization providing legal support to Aboriginal individuals.

The team of Gladue court workers plays a critical role in producing Aboriginal knowledges for the court. These practitioners, many of whom are Aboriginal, have received training on how to frame and position collective Aboriginal histories and individual case information within a legal discourse that is sensitive to the realities faced by Aboriginal peoples. Caseworkers know "what questions to ask; they know 
the significance of certain answers, such as where a person is originally from, and how to follow up on apparently inconsequential information" (Knazan 2003, 9-10). They have the expertise to describe how systemic issues affect Aboriginal peoples in general and the accused specifically. They are trained on available services, admission criteria, and levels of supervision and therefore are able to craft individualized plans of care. This team of experts plays an instrumental role in channelling information to the courts about how group experiences and histories can affect an Aboriginal offender. Moreover, they identify community supports that can be mobilised to address an offender's specific needs. They transform academic and oral narratives into supporting facts and legal evidence. Without this expert knowledge, legal professionals would be limited in their ability to adequately craft or envision alternative possibilities.

\section{Techniques for Producing Contextualized Aboriginal Knowledges}

Our analysis of court observations and interviews revealed that various techniques are used to ensure that the courts receive information regarding the "unique systemic or background factors" of the accused. In the majority of cases, evidence about Gladue factors is solicited through questioning of an offender or legal submissions. In more serious cases, or where custody is considered, a Gladue report is produced. The content of the questions, submissions, and reports demonstrates that the history of the accused, particularly evidence of past abuse, neglect, and discrimination, is central to the court process and can affect decision-making.

\section{Submissions and Questioning of the Accused}

We found that judges and lawyers do make a connection between "being Aboriginal" and the broader Aboriginal issues reflected in Gladue factors. Offenders are routinely asked to tell the court "something about their Aboriginal heritage," and the accused is often asked a series of questions designed to elicit information about various Gladue factors. The information offered in submissions and the types of questions asked of the accused are generally informed by discussions with the accused but also by information from Gladue caseworkers, who interact with the defendant and provide relevant information to the defence. Defence lawyers commonly begin by referring to the relevance of section 718.2(e) and then follow with an extensive line of questioning designed to draw connections between current charges and the contextualized history of the accused. In one sentencing hearing, the duty counsel called the client to the witness stand and began asking:

How old are you? 34

How many people are in that community? About 5,000, a lot of people come and go

Your status? Yes

You are Ojibwa? Yes

Where is your father from? First Nations ...

How were the conditions like [where you lived]? We lived in shacks ... very poor 
Was there a lot of violence on the reserve? Yeah

How long did you live there? Since I was young

Were you ever taken in by Children's Aid Society? Yeah (age 5)

How many foster homes did you stay in? 6 to 7 , I can't remember

Did you experience abuse in those homes? No

Do you know why you were put into Children Aid Society's care? I had a fetish for fires

Were you drinking at that young age? [Client notes that at age 5, he was given a six-pack of beer; that was the first time he got intoxicated]

What age did you start drinking regularly? 15

Has it been consistent all this time? Yeah

Was your mother a drinker? Yes

Is your dad a drinker? Chronic drinker

Has he been a chronic drinker all your life? He would take it easy for a few months, and then start again

Did you move a lot? Yes

You were diagnosed with bipolar disorder at age 15? Yeah

Where is some of your family? I don't really talk to my family ... called my dad on Fathers Day, was kind of weird

Do you know if your parents attended a residential school? My mother did.

[Court Observation TC6-260509]

Although this type of questioning varied in length, depth, and quality, these statements implicitly and explicitly highlight the legal relevance of Aboriginal issues that situate the offender within a much broader social and historical context. The tone of the questions reflects a combination of Aboriginal knowledges and legal knowledges, and the questions are based on issues that the courts consider legally relevant to bail and sentencing decisions, and to understanding and placing the offender within a broader historical and cultural context.

If insufficient evidence is brought before the court, judges will probe defendants to ensure that a composite history of the accused is entered as evidence, including a broad range of Gladue factors. For example:

Judge (to accused): "did your birth mother drink?" Accused: "yes”

Judge (to accused): "did you meet her before she died?" Accused: "no"

Judge (to accused): "were you taken away by an agency [as a child]?"

Accused: “yes." [Court Observation TC4-260509]

This line of questioning typifies how the courts are incorporating systemic and background factors mandated in R. v. Gladue. Judges routinely intervened and questioned defendants in an effort to solicit information pertaining to their Aboriginal histories. 
These courts pay special attention to the unique cultural identity of Aboriginal offenders, their background and circumstances. Our data revealed that the courts raise issues pertaining to formative upbringing, exposure to violence, parenting, family relations, and addictions, including prenatal use of alcohol by an offender's mother. The focus on prenatal alcoholism illustrates how lawyers and judges have adopted prevailing therapeutic knowledges and attempt to identify potential linkages between the criminal behaviour of Aboriginal offenders and the potential for fetal alcohol spectrum disorder (FASD); this theme appeared repeatedly in our court observations. We also found that issues such as the presence of intergenerational violence, attendance at residential schools, and FASD were expected, tacitly understood by the court, and rarely required further or independent expert verification by a psychological professional. These factors are implicitly acknowledged as important and relevant to the legal process. However, although the defence and Crown are now adopting a more contextualized line of inquiry, we found that they often stopped short of drawing connections between the individual, social, and family circumstances of the accused, the collective experiences of oppression by a community, and narratives of colonialism and historical race relations.

\section{Gladue Reports and their Contextualized Narratives}

Gladue reports introduce a substantively more sophisticated and nuanced layer of analysis that moves beyond the kinds of connections that judges and lawyers typically make between offenders' presenting behaviour and their personal family histories or group Aboriginal experiences. Gladue reports are an alternative form of sentencing report; they include a comprehensive overview of the social systemic factors facing an offender, and identify specific resources available in the community to address the needs of a particular offender. The level of contextualized group experiences included in these reports differs considerably from other offender reports such as pre-sentencing reports, which focus almost exclusively on individual behaviour and explanations. Hannah-Moffat and Maurutto (2010) argued that pre-sentence reports may identify and document typical Gladue factors such as lack of education, poverty, unemployment, and fragmented families, but they typically locate the cause of these factors within the individual, thereby elevating the perceived risk of offenders and the severity of the sanctions imposed. Williams (2009) noted that in cases involving female defendants, attention to systemic and cultural factors could reinforce perceptions of Aboriginal women and families as "incubators of risk." Gladue reports are distinctive in that they situate such factors within histories of race relations. They make explicit the linkages between political histories of race relations and the current treatment of Aboriginal peoples. More poignantly, the narratives implicate and demonstrate the role of the state in the production of criminal histories (and criminal records). In so doing, Gladue reports offer a different structure in which the voices and histories of Aboriginal peoples can be advanced within legal proceedings.

When preparing Gladue Reports, dedicated Aboriginal court workers typically engage in lengthy, in-depth interviews with the client, with his or her family members and acquaintances if possible, as well as with experts or specialists familiar with Aboriginal histories and communities. Reports characteristically include the 
following: a synopsis of the offence; the offender's past record; the offender's personal circumstances; the report writer's contact with the offender's family; options for services consistent with the proposed sentence; a plan for services to meet the offender's needs; contextualization of the offender's situation, including a description of the systemic issues affecting Aboriginal individuals; applications to, and arrangements made with, residential treatment facilities; and recommendations for sentencing (Campbell Research Associates 2008, 10). Significantly, these reports also clearly identify a treatment plan and recommend conditions.

Gladue reports normally draw on and cite expert information gathered from academic research, commissions of inquiry, and Aboriginal Elders to situate and explain the lingering effects of state policies on current Aboriginal realities. The following excerpt from a Gladue report exemplifies how secondary literature, in this case from the Royal Commission on Aboriginal Peoples (1996), can be used to account for the intergenerational trauma experienced by children and grandchildren of residential school survivors:

The residential school led to a disruption in the transference of parenting skills from one generation to the next. Without these skills, many survivors have had difficulty in raising their own children. In residential schools, they learned that adults often exert power and control through abuse. The lessons learned in childhood are often repeated in adulthood with the result that many survivors of the residential school system often inflict abuse on their own children. These children in turn use the same tools on their own children. [Gladue Report for Ms. X]

This account connects and situates the offender's abuse of her child within a historical group and cultural context where the prevalence of violence is, in large part, a function of state policies. For example, the report explains how:

[D] ue to the effects of colonialism and institutions such as the residential school experiences, rekindling motherhood has been one of the greatest challenges the Aboriginal community faces. Despite the broken chain between [Ms. X], her mother, grandmother and other generations of mothers, healing can take place. [Gladue Report for Ms. X]

This excerpt links residential school practices to the subsequent intergenerational trauma, which continues to linger and manifest across generations. The report then documents positive steps taken by the offender to initiate "healing." These accounts are used to support alternative outcomes that focus on healing and treatment within communities.

In another Gladue report, the writer methodically traced the offender's substance abuse and violent behaviour to the legacy of land dispossession that tore apart communities and disrupted family cohesion. The report identifies how federal policies forced Inuit populations to transform from a nomadic to a static lifestyle, resulting in community turmoil. The offender's charge of assault with a weapon while under the influence of alcohol is associated with the eradication of his cultural heritage:

Mr. M. lived a fairly traditional and semi-nomadic lifestyle for about the first six years of his life. After the age of six, living on the land became problematic because of the intrusion of Canadian law into the lives of the Inuit... 
.... [A] kaleidoscope of debilitating social and mental health problems result[ed] from a traumatic change in a way of life....

Alcoholism is often cited as a response to, and an escape from, the physical and psychological stresses of relocation and the depressing sense of loss and powerlessness among relocates. At Easterville, for example, alcoholism became a major problem after relocation. [Gladue Report for Mr. M]

This account exemplifies how Gladue reports make explicit the linkages between histories of assimilation, patterns of behaviour, and current offences. The implicit understanding is that this information is central to sentencing.

Gladue reports are powerful techniques used to package information, in a format that is accepted within legal structures. They document the linkages between individual behaviour and socio-cultural, political, historical, and economic processes, not necessarily with the goal of reducing the responsibility of the offender, but rather to understand and contextualize behaviour. These accounts and narratives mirror what critical race theorists and other legal scholars have identified as mechanism that operates to "overcome otherness," and bring to light "subjugated knowledges, by examining how history continues into the present, implicating individuals today" (Delgado 1989; Hill Collins 2000; Matsuda 1987; Williams 1991). Ultimately, they function to undermine the illusion of objectivity and practices that reinforce abstraction and decontextualization, thereby allowing for a more complex legal subject that can alter legal decision-making (Delgado 1989).

\section{Reconstituting the Legal Subject}

The previous section outlined various mechanism through which contextualized Aboriginal knowledges are infused into criminal justice proceedings within Gladue courts. In this section, we examine how the courts make use of these knowledges to reconstitute the Aboriginal legal subject. Our data revealed that judges and lawyers are influenced by previous cases, interactions with Aboriginal Legal Services and Aboriginal practitioners, and their own participation in Gladue courts. These experiences shape and alter how some judges adjudicate cases. Legal practitioners' ongoing interactions with Gladue information and the Aboriginal community produce a cumulative working knowledge of systemic Aboriginal issues; the process helps them to articulate and connect these issues to particular cases, and to make defensible and sometimes different decisions about sentencing or release. We found that the strategies and arguments used in one case were replicated in subsequent cases, indicating that practices can transcend individual cases to produce a new set of norms and precedents.

The following case exemplifies how judges consider various Gladue factors at sentencing and use them to defend a "second chance" and opportunity to embrace change. When sentencing an offender convicted of two assaults and failure to comply with bail and probation, the sentencing judge, in this case, noted:

It is a disturbing charge. You were drunk and have been drunk off and on. You were on recognizance at the time and on probation, you breached both of these and this was consistent with your record for similar offences since you were a young offender. The defense and Crown have petitioned to give 
you an opportunity to do something about the underlying issues with alcohol. This is a classic Gladue case-your background, the way you were raised, the dysfunctional family, alcohol abuse, foster care in non-traditional Aboriginal homes, and your early exposure to alcohol. You fell prey to it and you offended. It is part of the colonial heritage. With your own help this court can give you an opportunity to fix this. I must stress your responsibility, stop making excuses. Do you understand? [Court Observations TC10-210909; emphasis added]

This example demonstrates how offenders are not simply characterized as dysfunctional "risky" offenders, but as individuals who are situated within a "colonial heritage" that places them "at risk." This framing of the offender enables alternative ways of assessing an offender's prior record, his or her perceived level of risk, and the types of intervention required to minimize recidivism.

Criminal courts have traditionally considered a long criminal record to be an aggravating factor and used it to justify increased custody or pre-trial detention. Indeed, academic research about race and sentencing has identified how seemingly race-neutral sentencing policies that place heavy consideration on prior criminal record result in significantly higher rates of incarceration for racial minorities (Fraser 2009). The ability to locate offending behaviour within histories of race relations offers an opportunity to reconstitute how criminal records are used to cast legal subjects. In the following sentencing case, the exchange between duty counsel and the judge regarding an Aboriginal woman convicted of theft exemplifies one of the ways in which the reframing of criminal histories can occurs in Gladue courts:

[Duty counsel]: She is 29 years old. She is First Nations. She is the first born of an alcohol and crack addicted mother. She suffered a litany of abuse physical, sexual and then was placed into foster care where again she was physically and sexually abused. [...] She has a long criminal record but she has also been victimized and re-victimized throughout her life. Her problems are so deep and longstanding.

[Judge]: The crown is seeking a substantial sentence based on a very long record. I've considered your plea, what you have had to deal with in your life... I think time serviced is appropriate. I will suspend the sentence and place you on probation for 6 months. [Court Observations TC10-210545]

In this case, the court explicitly linked the individual's offending to a history of victimization - including possible FASD, systemic abuse, and neglect in foster care - to legitimate a non-custodial sentence. Our court observations suggested that these linkages are not intended to mitigate offender responsibility but to show how systemic factors embedded within shared Aboriginal history contribute to criminal records and over-incarceration; ideally, these linkages can help disrupt this cycle one case at a time. This process differs from traditional court practices, where factors such as a lengthy criminal history are generally used to demonstrate the "riskiness" of an offender and to justify detention or incarceration (Crow 2008; Roberts 1997). When an offender's behaviour is located within the broader experiences of victimization and disadvantage, it becomes possible to consider the extent to which he or she has been placed at risk and 
victimized; this moves the analysis beyond a narrow focus on his or her level of risk or risk of recidivism.

Factors that exacerbate recidivism, such as onerous conditions or lack of appropriate and timely programs, were often re-evaluated for their role in contributing to breaches and extensive criminal records. Within the courts, there was a tacit understanding that court-ordered conditions (on bail and/or probation orders) can themselves be problematic. Our observations showed that Gladue courts questioned the routine emphasis on a history of failure to comply charges to justify lengthy incarceration. We found that failure to comply with a court order did not automatically lead to the presumption of unmanageable risk. Rather, past conditions were often questioned and scrutinized to determine their contribution to common breaches. As a result, conditions were worded carefully to avoid "setting up" the offender for potential subsequent charges and incarceration. For example, in cases of substance abuse, judges were more likely to impose conditions involving "treatment for substance abuse," rather than using terms like "abstain from drugs and alcohol." In the following example, the judge reworded the Crown's recommendation that the offender was "not to be in possession of non-medically prescribed drugs." The judge during the sentencing hearing proceeded by asking:

[Judge]: Are you an addict?

[Accused]: Yes

[Judge]: I think that the "no drugs" term is not a good idea

[Duty Counsel]: Perhaps we can word it as "continue with drug and alcohol treatment" instead of no drugs. She is already in treatment. [Court Observations TC8-243350]

Moreover, when imposing treatment, judges frequently used indeterminatelyphrased counselling conditions to avoid inviting breaches. They often used the term "take counselling as directed," which leaves decisions about the type and frequency of counselling up to the Aboriginal caseworker or bail supervisor, enabling recommendations to be tailored to the specific individual. The careful wording of conditions is not exclusive to Gladue courts; our observations indicate that similar practices are occurring in other specialized courts such as Drug Treatment Courts. However, the lawyers we interviewed claimed that similar considerations do not typically occur in non-specialized criminal courts, or at least not to the same degree.

In cases where criminal records revealed a history of multiple breaches, we noted a broadening of discussion from an exclusive focus on past "failure to comply" charges toward greater consideration of an offender's "capacity to comply." The courts tended to focus on evidence of past ability to comply: duty counsel often highlighted gaps in criminal records, or "successes," using them as evidence of demonstrated stability in an offender's life and potential for rehabilitation in the community. Lengthy periods between breaches, or gaps, appeared as regular and accepted evidence of an individual's stability and progress. Demonstrated past progress and willingness to attend treatment programs was perceived as a positive indication that with a proper plan of care and support, the accused could be managed in the community. 
Although we observed clear shifts in the framing of Aboriginal legal subjects and changes in sentencing arguments, these were not in and of themselves a panacea. We also witnessed exceptions that provided some insight into how various judges interpret the relative importance of contextual Aboriginal and legal knowledges. These inconsistencies were most notable in cases where the accused had a lengthy criminal record, or where the offence was serious enough that a non-custodial sentence would be a significant departure from the norm. In a case involving an Aboriginal man who stole prime rib from a grocery store, the Crown and judge heard detailed information about the background of the accused and his involvement with a therapist and Aboriginal services. Nonetheless, the judge argued that:

Judge: I'm taking into account the factors of your Aboriginal heritage, but since the offense is not directly related to your Aboriginal heritage, I do not see why I should consider a different sentence. [Court Observations TC4-061609; the accused in this case received forty days in jail plus time served of five days]

This excerpt exposes some of the obstacles that persist as judges attempt to incorporate contextual knowledges and craft decisions that adhere to R. v. Gladue and $R$. v. Ipeelee. Tensions clearly exist, even in courts deliberately established to acknowledge the significance of how socio-cultural factors affect criminal conduct. Legal decision-making within Gladue courts does not abandon traditional legal principles; Gladue courts can be understood as integrating contextualized knowledges into existing legal structures defined by white, Western principles of justice. These courts and their practitioners are struggling to interpret and navigate new legal terrain and to devise new strategies that adhere to traditional liberal principles of law. Concurrently, they are assimilating new forms of contextualized Aboriginal knowledges and interpretations of R. v. Gladue and R. v. Ipeelee into law and legal practices. Our analysis demonstrates that Gladue principles circulate alongside conventional legal principles and can challenge but also reaffirm longstanding sentencing practices.

Moreover, we do acknowledge that the accumulation of contextualized knowledges can potentially result in harsher punishment, particularly from judges who lack training in Gladue principles and the specific objectives guiding Gladue courts. Moreover, there are apprehensions about how this information collected through Gladue courts might be used in subsequent cases or by penal institutions if one is imprisoned. Gladue reports become part of an offender's file that circulates with them. There is a lack of research on how this "contextual" information may be interpreted in diverse ways by juries in other courts, treatment officials, prison staff, or in parole decisions. That said, emerging patterns in Gladue courts indicate that contextualized Aboriginal knowledges are giving rise to new legal arguments and practices that are shifting conventional legal evidence, arguments, and sentencing outcomes.

\section{Conclusions}

Gladue courts have created a new space for Aboriginal contextualized knowledge and alternative ways of characterizing Aboriginal risk. The courts promote 
awareness of how social structures and legal processes continue to criminalize Aboriginals, and invite a broader recognition of the need and responsibility of the court to assess these effects and modify practices. Contextualized Aboriginal knowledges allow legal professionals to reformulate conditions and to see the court process as a latent issue that has contributed to the over-incarceration and systemic discrimination of Aboriginal peoples. This context enables judges, lawyers, and others to present the court with creative alternatives for sentencing and bail. Over time, these will contribute to a body of jurisprudence that may be more responsive to racialized histories of exploitation, colonialism, and context, but in doing so will likely have some unanticipated consequences.

\section{References}

Aylward, Carol. 1999. Canadian Critical Race Theory: Racism and the Law. Halifax, NS: Fernwood Publishing.

Balfour, Gillian. 2008. Falling between the cracks of retributive and restorative justice: The victimization and punishment of aboriginal women. Feminist Criminology 3 (2): 101-20.

Battiste, Marie, and James (Sa'ke'j) Youngblood Henderson. 2000. Current international reforms. In Protecting Indigenous Knowledge and Heritage. Saskatoon, SK: Purich Publishing Ltd.

Campbell Research Associates. 2008. Evaluation of the Aboriginal Legal Service of Toronto Gladue Caseworker Program. Year Three. October 2006 - September 2007. Mississauga, ON: Campbell Research Associates.

Canadian Superior Court Judges Association. 2006. The Role of the Judge. Accessed at: http://www.cscja-acjcs.ca/role_of_judge-en.asp?l=5.

Crenshaw, Kimberle Williams. 2005. A black feminist critique of antidiscrimination law. In Philosophical Problems in the Law, $4^{\text {th }}$ ed., ed. $\backslash$ David M. Adams, 339-43. Florence, KY: Wadsworth.

Crow, Mathew S. 2008. The complexities of prior record, race, ethnicity and policy. Criminal Justice Review 33 (4): 502-23.

Daubney, David. 2002. Nine words: A response to "empty promises": Parliament, the Supreme Court, and the sentencing of aboriginal offenders. Saskatchewan Law Review 65: 35-52.

Dei, George Sefa, and Furpreet Singh Johal, eds. 2005. Critical Issues in Anti-Racist Research Methodologies. New York: Peter Lang.

Dei, George Sefa, Budd Hall, and Dorothy Goldin Rosenburg, eds. 2002. Indigenous Knowledges in Global Context. Toronto: University of Toronto Press.

Delgado, Richard. 1989. Storytelling for oppositionists and others: A plea for narrative. Michigan Law Review 87: 2411-41.

Delgado, Richard, and Jean Stefancic. 2000. Critical Race Theory: The Cutting Edge. Philadelphia: Temple University Press.

Ewick, Patricia, and Susan S. Silbey. 1995. Subversive stories and hegemonic tales: Toward a sociology of narrative. Law and Society Review 29: 197-226.

Foucault, Michel. 1994. An interview with Michel Foucault. In Power (Vol. 3), ed. J. F. Faubion. New York: The New Press.

. 1980a. Ethics, Subjectivity, and Truth: Essential Works of Foucault, 1954-1984, Vol. 1. ed. Paul Rabinow. New York: Pantheon Press.

. 1980b. Power/Knowledge: Selected Interviews and Other Writings: 1972-1977. ed. by

C. Gordon. New York: Pantheon. 
Fraser, Richard S. 2009. What explains persistent racial disproportionality in Minnesota's prison and jail populations? Crime and Justice, An Annual Review of Research 38: 201-80.

Garland, David. 2001. The Culture of Crime Control and Social Order in Contemporary Society. Oxford: Oxford University Press.

Hannah-Moffat, Kelly, and Paula Maurutto. 2010. Restructuring pre-sentence reports: Race, risk, and the PSR. Punishment and Society 12 (3): 262-86.

Hart, Michael. 2007. Indigenous knowledge and research: The Míkiwáhp as a symbol for reclaiming our knowledge and ways of knowing. First Peoples' Child and Family Review 3 (1): 83-90.

Hill Collins, Patricia. 2000. Black feminist thought. In Theories of Race and Racism: A Reader, ed. Les Black and John Solomos, 404-20. London: Routledge.

Kovach, Margaret. 2010. Indigenous Methodologies: Characteristics, Conversations, and Context. Toronto: University of Toronto Press.

Knazan, Justice Brent. 2003. Sentencing Aboriginal Offenders in a Large City. The Toronto Gladue (Aboriginal Persons) Court. Calgary, AB: National Justice Institute Aboriginal Law Seminar. Retrieved from Aboriginal Legal Services of Toronto website: http:// www.aboriginallegal.ca/assets/gladuesentencingpaper.pdf.

- 2005. The Toronto Gladue (Aboriginal Persons) Court: An Update. St. John's, NF: National Justice Institute Aboriginal Law Seminar.

- 2009. Time for justice: One approach to R. v. Gladue. Criminal Law Quarterly 54 (4): 431-46.

Law Reform Commission of Canada. 1991. Aboriginal Peoples and Criminal Justice: Equality, Respect and the Search for Justice. Ottawa, ON: Law Reform Commission of Canada.

Lawrence, Sonia, and Toni Williams. 2006. Swallowed up: Drug couriers at the borders of Canadian sentencing. University of Toronto Law Journal 56 (4): 285-332.

Matsuda, Mari. 1987. Looking to the bottom: Critical legal studies and reparations. Harvard Civil Rights - Civil Liberties Law Review 22 (2): 323.

-1996. Where is Your Body? And Other Essays on Race, Gender and Law. Boston: Beacon Press.

Milward, David, and Debra Parkes. 2011. Gladue: Beyond myth and towards implementation in Manitoba. Manitoba Law Journal 35 (1): 84-110.

Monture-Angus, Patricia. 1999. Women and risk: Aboriginal women, colonialism, and correctional practice. Canadian Woman Studies 19: 24-29.

Murdocca, Carmela. 2006. National responsibility and systemic racism in criminal sentencing: The case of R. v. Hamilton. In The Place of Justice, ed. Nicholas Blomley and Sean Robertson, 67-94. Vancouver, BC: Fernwood Publishing.

Parkes, Debra. 2012. Ipeelee and the pursuit of proportionality in a world of mandatory minimum sentences. For the Defence 33 (3): 22-27.

Perreault, Samuel. 2009. The incarceration of aboriginal people in adult correctional services. Juristat. no. 85-002-X, 29 (3): 1-27.

Roach, Kent, and Jonathan Rudin. 2000. Gladue: The judicial and political reception of a promising decision. Canadian Journal of Criminology 42 (3): 355-88.

Roberts, Julian. 1997. The Role of the Criminal Record in the Sentencing Process. Crime and Justice 22: 303-62.

Royal Commission on Aboriginal Peoples. 1996. Bridging the Cultural Divide: A Report on Aboriginal People and Criminal Justice in Canada. Ottawa, ON: Supply and Services Canada.

Rudin, Jonathan, and Kent Roach. 2002. Broken promises: A response to Stenning and Roberts' 'Empty Promises.' Saskatchewan Law Review 65 (3): 3-34.

Rudin, Jonathan. 2012. Looking backward, looking forward: The Supreme Court of Canada's decision in R. v. Ipeelee. The Supreme Court Law Review 57: 375-88. 
Smith, Linda Tuhiwai. 2012. Decolonizing Methodologies: Research and Indigenous Peoples. London: Zed Books Ltd.

Truth and Reconciliation Commission of Canada. 2015. Honouring the Truth, Reconciling for the Future: Summary of the Final Report of the Truth and Reconciliation Commission of Canada. Winnipeg, MB: Truth and Reconciliation Commission of Canada.

Valverde, Mariana. 2003. Law's Dream of a Common Knowledge. Princeton, NJ: Princeton University Press.

Vancise, William J., and Patrick Healy. 2002. Judicial notice in sentencing. Saskatchewan Law Review 65: 97-105.

Williams, Patricia. 1991. The Alchemy of Race and Rights. Cambridge, MA: Harvard University Press.

Williams, Toni. 2009. Intersectionality analysis in the sentencing of aboriginal women in Canada: What difference does it make. In Intersectionality and Beyond: Law, Power and the Politics of Location, ed. E. Grabham, D. Cooper, J. Krishnadas, and D. Herman, 79-104. Abingdon, UK: Routledge-Cavendish.

\section{Cases cited}

R. v. Bain, [2004] O.J. No. 6147

R. v. Borde, (2003) 63 O.R. (3d) 417 (ON CA)

R. v. Crawford, (2007) 76 W.C.B. (2d) 445 (Ont. S.C.J.)

R. v. Gladue, [1999] 1 SCC 688

R. v. Ipeelee, [2012] SCC 13

R. v. Jensen, (2005) 1960 O.A.C. 119

R. v. Kakekagamick, (2006) 214 O.A.C. 127

R. v. Hamilton, (2005) 2 S.C.R. 432

Paula Maurutto

Department of Sociology, University of Toronto

p.maurutto@utoronto.ca

Kelly Hannah-Moffat

Centre for Criminology and Sociolegal Studies,

University of Toronto

hannah.moffat@utoronto.ca 